\title{
Effectiveness of healthcare worker screening in hospital outbreaks with gram- negative pathogens: a systematic review
}

\author{
Nikos Ulrich ${ }^{1 *}$ (D) Petra Gastmeier ${ }^{1}$ and Ralf-Peter Vonberg ${ }^{2}$
}

\begin{abstract}
Background: Identifying the source of an outbreak is the most crucial aspect of any outbreak investigation. In this review, we address the frequently discussed question of whether (rectal) screening of health care workers (HCWs) should be carried out when dealing with outbreaks caused by gram negative bacteria (GNB). A systematic search of the medical literature was performed, including the Worldwide Outbreak Database and PubMed. Outbreaks got included if a HCW was the source of the outbreak and the causative pathogen was an Escherichia coli, Klebsiella spp., Enterobacter spp., Serratia spp., Pseudomonas aeruginosa, or Acinetobacter baumannii. This was true for 25 articles in which there were 1196 (2.1\%) outbreaks due to GNB, thereof 14 HCWs who were permanently colonized by the outbreak strain. Rectal screening of HCWs was helpful in only 2 of the $1196(0.2 \%)$ outbreaks. Instead, the hands of HCWs served as a reservoir for the outbreak strain in at least 7 articles - especially when they suffered from onychomycosis or used artificial fingernails or rings.

Conclusion: Due to very weak evidence, we do not recommend rectal screening of HCWs in an outbreak situation with GNB. However, besides a critical review of hand hygiene habits, it might be useful to examine the hands of staff carefully. This measure is cheap, quick to perform, and seems to be quite effective.
\end{abstract}

Keywords: Outbreak, Gram negative, Health care worker, Screening

\section{Background}

The value of screening healthcare workers (HCWs) during an investigation of a nosocomial outbreak is yet unclear. There is some evidence, that this may be a beneficial measure when dealing with Staphylococcus aureus as the causative agent, if there is a clear epidemiological link between an individual HCW and the occurrence of Staphylococcus aureus infections among patients while no other outbreak source seems likely [1]. This is because decolonization strategies exist for this particular pathogen. However, even in Methicillinresistant Staphylococcus aureus (MRSA) outbreaks, HCWs are rarely identified as its cause: A systematic review on 191 nosocomial MRSA outbreaks showed that in only $11, \mathrm{HCW}$ s were the outbreak's source. Among them were $3 \mathrm{HCW}$ ( $1.6 \%$ of all nosocomial MRSA

\footnotetext{
* Correspondence: nikos-konstantin.ulrich@charite.de

${ }^{1}$ Charité - Institute for Hygiene and Environmental Medicine,

Charité-University Medicine Berlin, Berlin, Germany

Full list of author information is available at the end of the article
}

outbreaks) that were asymptomatic carriers who would normally have been missed had the screening of staff not taken place. The remaining $8 \mathrm{HCWs}$ had MRSA infections themselves, which means that screening does not give any additional information [2]. Personnel screening can be useful in certain situations and certain pathogens. In a nosocomial Outbreaks in the USA in 1996 and 1997 $\mathrm{HCW}$ screening was initiated after postpartum Group A streptococcus (GAS) was observed in 9 patients. After a case-control study, they found that exposure to one HCW was strongly associated with infection of GAS. As a consequence, screening of $198 \mathrm{HCW}$ resulted in three positive tests. However, only one HCW's test culture matched the outbreak strain. The HCW had a rectal colonisation. After antibiotic treatment of the HCW there were no additional cases in the hospital [3].

Even less is known about this matter when dealing with nosocomial outbreaks caused by gram negative bacteria (GNB). National guidelines differ in terms of whether HCW screening should be applied or not. 
Whereas the ESCMID (European Society of Clinical Microbiology and Infectious Diseases) for example recommends HCW screening for outbreaks with some pathogens, the PHE (Public Health England) CPE guidelines do not recommend $\mathrm{HCW}$ screening [4]. A recently published systematic review of outbreaks due to extended spectrum beta-lactamase (ESBL)-producing Enterobacteriaceae in neonatal intensive care units (NICU) mentioned screening of staff and environmental screening as the main infection control procedures: A total of 75 articles were included, 60 of them provided information regarding infection control measures, thereof 29 outbreak reports, in which screening of HCW was performed [5].

Screening of HCWs during an outbreak investigation may be difficult because the detection of the outbreak strain in swabs from HCWs does not necessarily prove the direction of pathogen spread (chicken vs. egg). Therefore, there is a need for a compre-hensive analysis of this measure, in particular nosocomial outbreaks caused by GNB.

\section{Methods}

\section{Databases}

The Worldwide Outbreak Database (www.outbreakdatabase.com) is the largest collection of nosocomial outbreaks. Currently it contains more than 3500 systematically filed outbreak reports as published in the medical literature between 1972 and today [6, 7]. The advanced search mode allows the user of this database to combine parameters of interest. For this systematic review, the first parameter "SC (Outbreak/Development/ Source/Type)" was set to "Personnel" and consecutively the second parameter "SP (Outbreak/Microorganisms/ Microorganism/Genus/Species/Name)" was set to either one of the following six types of nosocomial pathogens: Escherichia coli, Klebsiella spp., Enterobacter spp., Serratia spp., Pseudomonas aeruginosa, and Acinetobacter baumannii (Fig. 1) resulting in 6 separate searches (one for each pathogen). We thereby only retrieved articles in which Personnel was the source of the outbreak of the specified pathogen. The database was accessed on July 25th of 2017.

In addition, PubMed (www.ncbi.nlm.nih.gov/pubmed) was searched on the same day using the following search algorithm: ((nosocomial) AND (outbreak OR epidemic)) AND (Escherichia OR Klebsiella OR Enterobacter OR Serratia OR Pseudomonas OR Acinetobacter).

Finally, all reference lists of the retrieved articles were checked for any further relevant articles that might have been missed.

\section{Inclusion and exclusion criteria}

Outbreak reports were included, if a member of hospital staff was considered the probable or proven cause of an outbreak caused by one of the abovementioned pathogens. There were no restrictions with respect to the type of medical department, geographical origin or date. Articles in German and English were considered for this review.

The majority of these species are part of the human physiological gut flora. That is why screening for GNB is normally carried out by rectal swabs, culturing of stool samples, or perianal screening [8], although colonisation may also occur at other body sites [9]. However, hands of $\mathrm{HCWs}$ are considered the most important vector for the transmission of nosocomial pathogens and, thus, often become part of screening programs, too (although the flora on hands very much depends upon the compliance to hand hygiene). Taking those facts into consideration, it is justifiable to differentiate between gut colonisation, temporary hand contamination, and permanent hand colonisation and/or infection. This systematic review focuses on the epidemiologically most relevant group, HCWs who carry GNB on their hands permanently.

\section{Data extraction}

The following items were extracted from each outbreak report: country, department, risk factors, type of infections, duration, pathogen species, the number of patients

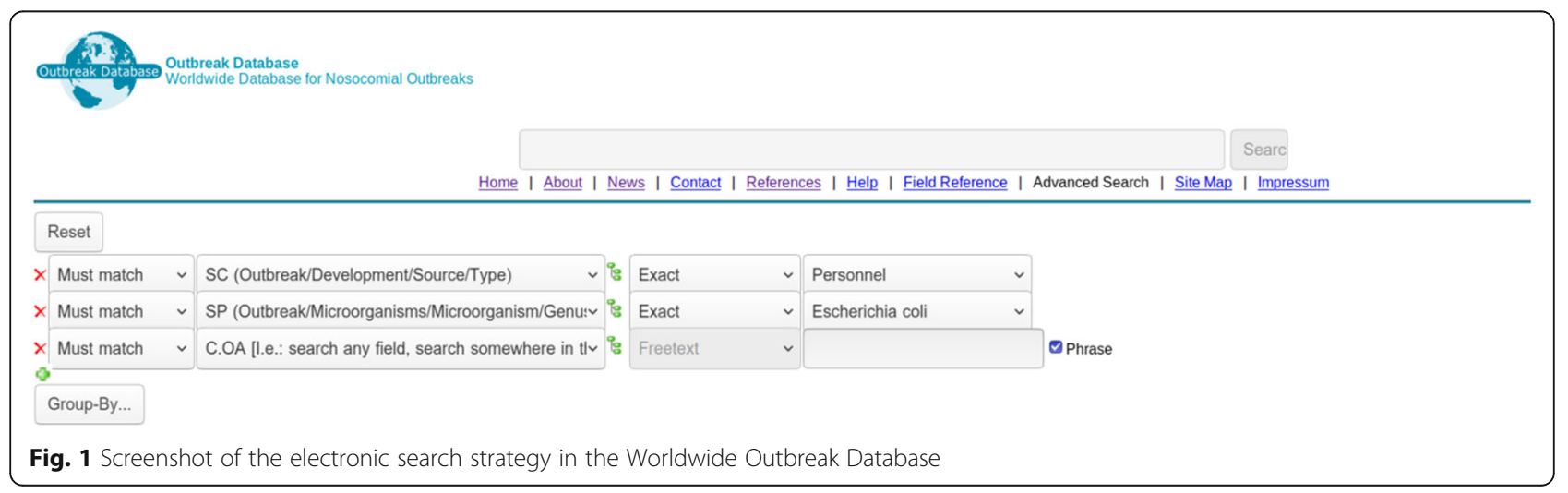


involved, mortality, location of colonisation and/or infection of personnel (if applicable), typing method, and typing results.

N.U. carried out the literature review. P.G. independently accessed the content of included articles. Any deviations were discussed and settled by discussion of all three authors (N.U., P.G. and R.P.V.).

\section{Results}

The Worldwide Outbreak Database contained 3551 outbreaks overall, of which 1196 outbreaks were caused by the aforementioned GNB (E. coli: 80; Klebsiella spp.: 318; Enterobacter spp.: 121; Serratia spp.: 175; P. aeruginosa: 255; A. baumannii: 247). The PubMed search, as described, retrieved 1002 potentially relevant articles however all of those were already covered by the primary search of the Worldwide Outbreak Database. No further references were found by checking the citation lists.

All articles in the Worldwide Outbreak Database are already filed in a standardized manner (which allowed the stratified search in the first place) including stratification by the outbreak's source. HCWs were considered to be the actual source of the nosocomial outbreak in 35 [10-44] of the 1002 reports (= $3.6 \%$ ) by the authors of the articles. However, we had to exclude $10[10,13,16,18,19,28,30,35,42,44]$ articles after full text reading because they either provided insufficient evidence, had a general lack of data, took place at facilities other than hospitals (e.g., long term care facilities), or did not focus on GNB in particular. The colonisation status of the HCWs in the remaining 25 articles were either transient (11 articles) or permanent (14 articles). In 10 of the 14 permanently colonised HCWs, screening of hands was performed and were finally included in this systematic review $[20,25,27,29,31,32,34,36,39,41]$. Figure 2 shows the corresponding flow chart of the inclusion algorithm of the literature.

The 10 included articles were published between 1970 and 2005 and involved at least 164 patients. Neonatology/

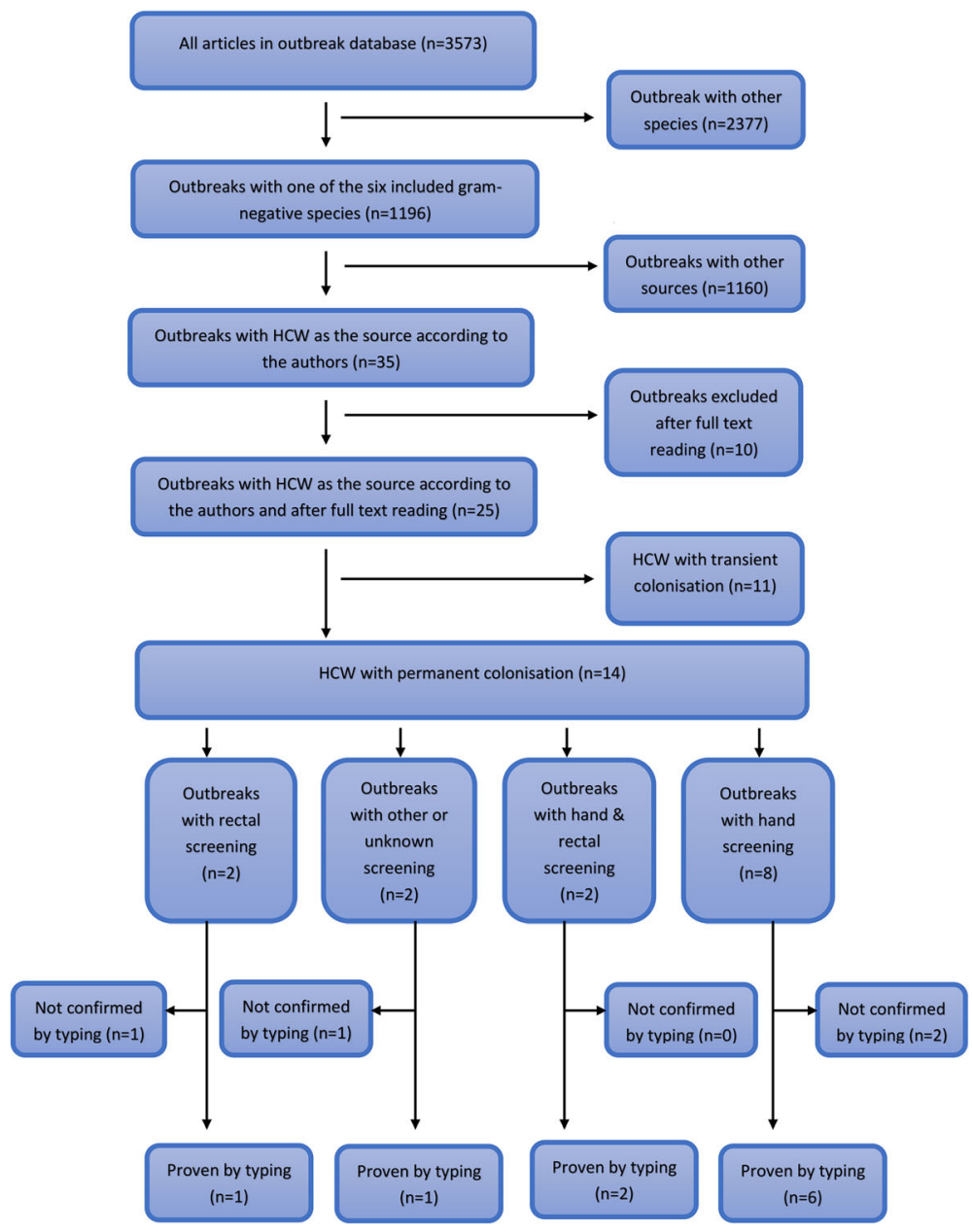

Fig. 2 Prisma flow diagram according to the search protocol 
nursery and surgery were affected by those events (Table 1). The most frequently observed infections in those 10 outbreaks were bloodstream infections $(n=19)$, wound infections $(n=15)$ and infections of the mediastinum and the pleural cavity $(n=10)$ (for further information see Additional file 1). "Non-physiological conditions of the fingers and hands", such as onychomycosis, use of artificial nails, and rings, played important roles in 7 of the 10 outbreaks (Table 1 ).

Falcao et al. [32] describes a polyphasic outbreak event in a nursery in Brazil due to multiple Pseudomonas aeruginosa strains. Overall, 27 children were infected or colonised by at least three different strains. One of those outbreak strains was found in an oxygen bubbler used for premature infants as well as in a rectal swab of a nurse. Screening of hands of staff was not reported. The authors assume that this nurse was the primary source of the spread of that strain via subsequent contamination of the medical device. Three other nurses were also carriers of Pseudomonas aeruginosa strains, but they showed different microbiological patterns and were therefore considered unrelated to the outbreak.

Passaro et al. [41] published the last outbreak report that was included in this systematic review: Seven patients in cardiovascular surgery acquired postoperative infections with a Serratia marcescens strain. Once again, artificial fingernails, used by a scrub nurse, were the most probable source of the outbreak. A contaminated jar of exfoliant cream at the nurse's home served as a constant source for re-contamination of the nails. No more infections occurred when this jar had been discarded.

Moolenaar et al. [36] describe a Pseudomonas aeruginosa outbreak in a NICU affecting 46 patients; 16 patients deceased. HCWs were screened as a possible source and the outbreak strain was subsequently found on the hands of $2 \mathrm{HCWs}$, one of them with long artificial nails and the other one with long natural nails. A third nurse with short natural fingernails was also identified as a carrier of Pseudomonas aeruginosa, but this strain was not related to the outbreak.

A total of 16 postoperative wound infections from Pseudomonas aeruginosa were observed in an outbreak in a thoracic surgical department as mentioned by McNeil et al. [34]. The outbreak's source could be traced to a nurse, who suffered from severe chronic ( $>2$ years) onycholysis of her right thumbnail. This lesion had remained unnoticed by her colleagues because it was constantly covered with flesh-colored nail polish. There were no additional cases as soon as this nurse abstained from further surgical procedures and her subsequent return to work with the previously infected thumbnail totally removed.

Taneja et al. [20] describe an outbreak in an Indian NICU caused by an enterotoxigenic Escherichia coli (ETEC) affecting 16 neonates. Swabs from various environmental sites and from all components of the milk feed

Table 1 Nosocomial outbreaks caused by health care workers involving gram negative bacteria

\begin{tabular}{|c|c|c|c|c|c|c|}
\hline $\begin{array}{l}\text { Autor, year, } \\
\text { reference }\end{array}$ & Pathogen & Department & $\begin{array}{l}\# \\
\text { Patients }\end{array}$ & $\begin{array}{l}\text { Microbiologically } \\
\text { proven }\end{array}$ & $\begin{array}{l}\text { Pathogen identified by } \\
\text { rectal swabs }\end{array}$ & $\begin{array}{l}\text { Location at personnel } \\
\text { (colonisation and/or infection) }\end{array}$ \\
\hline $\begin{array}{l}\text { Falcao et al. } 1972 \\
\text { [32] }\end{array}$ & $\begin{array}{l}\text { Pseudomonas } \\
\text { aeruginosa }\end{array}$ & Nursery & 9 & yes & yes & - faeces \\
\hline $\begin{array}{l}\text { Passaro et al.1997 } \\
\text { [41] }\end{array}$ & Serratia marcescens & Surgery & 7 & yes & no & - hands (artificial nails) \\
\hline $\begin{array}{l}\text { Moolenaar et al. } \\
2000[36]\end{array}$ & $\begin{array}{l}\text { Pseudomonas } \\
\text { aeruginosa }\end{array}$ & $\mathrm{NICU}$ & 46 & yes & no & - hands (fingernails) \\
\hline $\begin{array}{l}\text { McNeil et al. } 2001 \\
{[34]}\end{array}$ & $\begin{array}{l}\text { Pseudomonas } \\
\text { aeruginosa }\end{array}$ & Surgery & 16 & yes & no & $\begin{array}{l}\text { - hands (onychomycosis and } \\
\text { fingernails) }\end{array}$ \\
\hline $\begin{array}{l}\text { Taneja et al., } 2003 \\
{[20]}\end{array}$ & $\begin{array}{l}\text { Escherichia coli } \\
\text { (ETEC) }\end{array}$ & $\mathrm{NICU}$ & 16 & yes & yes & $\begin{array}{l}\cdot \text { hands } \\
\cdot \text { faeces }\end{array}$ \\
\hline $\begin{array}{l}\text { Zawacki et al. } 2004 \\
\text { [31] }\end{array}$ & $\begin{array}{l}\text { Pseudomonas } \\
\text { aeruginosa }\end{array}$ & $\mathrm{NICU}$ & 5 & yes & no & $\begin{array}{l}\cdot \text { hands } \\
\cdot \text { ear }\end{array}$ \\
\hline $\begin{array}{l}\text { Gupta et al. } 2004 \\
{[25]}\end{array}$ & $\begin{array}{l}\text { Klebsiella } \\
\text { pneumoniae (ESBL) }\end{array}$ & $\mathrm{NICU}$ & 19 & yes & no & - hands (artificial nails) \\
\hline $\begin{array}{l}\text { Boszczowski et al. } \\
2005 \text { [27] }\end{array}$ & $\begin{array}{l}\text { Klebsiella } \\
\text { pneumoniae (ESBL) }\end{array}$ & $\mathrm{NICU}$ & 4 & yes & no & - hands (onychomykosis) \\
\hline $\begin{array}{l}\text { Jepson et al. } 2006 \\
\text { [39] }\end{array}$ & Serratia marcescens & Surgery & 6 & yes & no & - hands (ring) \\
\hline $\begin{array}{l}\text { Cassettari et al. } \\
2009[29]\end{array}$ & $\begin{array}{l}\text { Klebsiella } \\
\text { pneumoniae (ESBL) }\end{array}$ & $\begin{array}{l}\text { Neonatal Intermediate } \\
\text { Care Unit }\end{array}$ & 36 & yes & no & $\begin{array}{l}\text { - hands (onychomycotic } \\
\text { lesions) }\end{array}$ \\
\hline
\end{tabular}


were cultured. Staff of the dietetics department, where the reconstituted milk was prepared were also screened through the use of stool samples and swabs from hands. Besides some kitchen equipment, the hands and the stool sample of one cook was found to be ETEC positive. The outbreak terminated after his temporary removal from work for gut decontamination and enforcement of hand hygiene as well as food hygiene measures.

Zawacki et al. [31] describe a Pseudomonas aeruginosa outbreak on an NICU in Massachusetts. Four of the five affected infants developed pneumonia and a secondary bloodstream infection and ultimately died. Patients as potential reservoirs were ruled out. Then the infection control team screened the hands of HCWs and found five HCWs repeatedly tested positively for Pseudomonas aeruginosa, but only one of them carried the outbreak strain as confirmed by genotyping by pulsed-field gel electrophoresis (PFGE). The occupational health service took additional samples from other body sites and diagnosed an intermittent otitis externa colonised by this particular Pseudomonas aeruginosa strain.

Gupta et al. [25] report another NICU outbreak of ESBL-producing Klebsiella pneumoniae. Nineteen infants were infected or colonised by the outbreak strain. The identical strain was also found on the hands of two HCWs as shown by PFGE. One of those HCW wore artificial nails; the other had simply a longer nail length. Both HCWs were found to be negative in rectal swabs and urine samples. No new cases occurred after the HCWs removed the artificial nails or shortened the natural finger nails respectively.

Boszczowski et al. [27] describe an outbreak in a Brazilian NICU. Four patients were affected by the outbreak. Of those 4 patients, 3 developed a bacteremia and 1 patient a urinary tract infection. The outbreak strain was found on the hands of one assistant nurse, who suffered from onychomycosis. No new cases occurred as soon as she was removed from patient care.

Six postoperative wound infections by Serratia marcescens are reported from Jepson et al. [39] most probably caused by an assistant surgeon, who was unable to remove his very tightly fitted rings from his fingers. A strain indistinguishable by PFGE from the outbreak strain was cultured from that location. No further infections were noticed as soon as this HCW was requested to abstain from further operations until his rings had been removed.

Cassettari et al. [29] report nosocomial transmissions of ESBL-producing Klebsiella pneumoniae in an intermediaterisk neonatal unit in Brazil. The outbreak was noticed when nine patients were affected. Twenty-seven additional patients were colonised thereafter despite implementation and rigorous enforcement of numerous infection control measures. Finally, a nurse was identified who had harboured the outbreak strain (identical pulsed-field gel electrophoresis (PFGE) pattern) in onychomycotic lesions on her fingers. The outbreak terminated when she was removed from duty for topical and systemic antimicrobial therapy. Further investigation for potential intestinal carriage was considered unnecessary.

\section{Discussion}

Newborn care in general and NICUs in particular were the main medical departments affected by outbreaks of GNB in this review. There are several other reports that add to this observation. For example, Haller et al. described a sustained outbreak of ESBL-producing Klebsiella pneumoniae in Bremen (Germany) in a NICU affecting 37 patients, of which 10 developed a bloodstream infection (7 fatal cases). This outbreak was detected in 2011 but retrospective analysis of charts revealed cases already back in 2009. The authors conclude that the strain must have been endemic since 2008 and that person-to-person transmission was the most likely route of transmission. Screening of 328 members of staff was performed as part of the outbreak investigation by perianal swabs. As a result, there were $293 \mathrm{HCW}$ that were screened at least three times. However, the outbreak causing strain could not be detected in any of those samples; the actual source of the outbreak remained unclear $[42,45]$. Of relevance, there were additional outbreaks by GNBs in German NICUs in 2010 until 2012. This accumulation of similar events finally caught the attention of the national media and public awareness which resulted in extensive screening of personnel [46].

However, screening of staff and pointing the finger on positive members may cause severe problems. Finding an outbreak pathogen on a HCW can easily lead to the feeling of guilt and stigmatisation among staff. The subsequent leave of absence, especially when unpaid, together with the fear of compensation might pose a financial challenge to the affected HCWs. These concerns make HCW screening a problematic topic and therefore a wellbalanced decision between advantages and possible disadvantages should be made [1]. A more transparent discussion about all pro's and con's of such measures might be the best way to deal with this matter, especially if mainstream pressure from public media arises.

Decker et al. [47], conducted a case-control observational study including $400 \mathrm{HCW}$. They tested their rectal colonisation with multi-drug resistant gram-negative bacteria and vancomycin-resistant enterococci (VRE) through self-collected perirectal swabs and a questionnaire. They found that in the HCW group 4\% (15/379) and in the control group $3.2 \%(12 / 376)$ of participants were colonised with multi-drug resistant gram-negative bacteria. This is in accordance with our data, which 
shows that staff is rarely the source of an outbreak with gram-negative bacteria.

However, instead of rectal screening much more attention should be paid to any unusual findings on hands of HCWs in outbreak situations. In 7 out of the 10 outbreaks in which a HCW was proven to be the source of an outbreak, the source mostly consisted of nonphysiological conditions of their hands (e.g., use of artificial nails, rings or onychomycotic lesions). A careful glance of the hands of HCWs should therefore be considered before starting any extensive screening of otherwise healthy personnel on other body sites [48, 49]. Any rings should be removed before working at the patient's site and any guidelines, in which "It is recommended that $[. .$.$] wedding rings may continue to be worn by$ 'scrub' and 'non-scrub' staff [...]." should be revised accordingly [50].

The main limitation of our study is its retrospective approach. We can only rely on published outbreaks that were available by the search strategy applied as described. So there might be other relevant articles on this topic, which were missed. In addition, we lack a quality control scale and, thus, did not systematically evaluate the quality of the primary studies included in this review. Furthermore, the overall quality of outbreak descriptions still needs improvement as they often lack important information about the event $[51,52]$. Thus, we herewith would like to encourage future authors and publishers to better adhere to the Outbreak Reports and Intervention Studies Of Nosocomial infection (ORION) guidelines in upcoming manuscripts [53].

\section{Conclusion}

The data of this review shows that HCWs are extremely rarely the primary source of nosocomial outbreaks by GNB $(25 / 1196=2.1 \%)$. Moreover, even if they are, it is apparent that their hands are much more important than an intestinal colonisation. Given these rather low numbers, a rectal screening of staff without signs of infection seems pointless, especially in light of the low sensitivity, high cost and discomfort for the HCW [54]. Due to the very weak evidence for the usefulness of a rectal $\mathrm{HCW}$ screening in identifying the source of an outbreak with GNB and the difficulties in interpreting screening results appropriately, we do not recommend HCW screening during outbreaks caused by GNB. Only in case of clear indications, e.g. GI tract infection or a strong correlation between a $\mathrm{HCW}$ and affected patients, should HCW screening be an option. Of course, adherence to proper hand hygiene is very much encouraged.

\section{Additional file}

Additional file 1 Detailed table on extracted data. (XLSX $14 \mathrm{~kb}$ )

\section{Abbreviations}

ESBL: extended spectrum beta-lactamase; ETEC: enterotoxigenic Escherichia coli; GNB: Gram negative bacteria; HCW: Healthcare worker;

MRSA: Methicillin-resistant Staphylococcus aureus; NICU: Neonatal intensive care unit; PFGE: Pulsed-field gel electrophoresis

\section{Acknowledgements}

We thank Ms. Alexandra Buchanan for her constant English language support during the process of writing this article.

\section{Funding}

This article received no funding.

\section{Availability of data and materials}

All data used in this article are available through Pubmed/Medline.

The dataset supporting the conclusions of this article is included within the Additional file.

\section{Author's contributions}

NU carried out the literature review and drafted the manuscript. PG made substantial contributions to the study design, the interpretation of data and in overlooking the research. RPV has been involved in revising the manuscript and has made a critical contribution to the article in its current form. All three authors were involved in the process of writing the article. All authors read and approved the final manuscript.

Ethics approval and consent to participate

Not applicable.

\section{Consent for publication}

Not applicable.

\section{Competing interests}

The authors declare that they have no competing interests.

\section{Publisher's Note}

Springer Nature remains neutral with regard to jurisdictional claims in published maps and institutional affiliations.

\section{Author details}

${ }^{1}$ Charité - Institute for Hygiene and Environmental Medicine, Charité-University Medicine Berlin, Berlin, Germany. ${ }^{2}$ Institute for Medical Microbiology and Hospital Epidemiology, Hannover Medical School, Hannover, Germany.

Received: 27 October 2017 Accepted: 25 February 2018

Published online: 09 March 2018

References

1. Albrich WC, Harbarth S. Health-care workers: source, vector, or victim of MRSA? Lancet Infect Dis. 2008;8:289-301.

2. Vonberg RP, Stamm-Balderjahn S, Hansen S, Zuschneid I, Ruden H, Behnke M, Gastmeier P. How often do asymptomatic healthcare workers cause methicillin-resistant Staphylococcus aureus outbreaks? A systematic evaluation. Infect Control Hosp Epidemiol. 2006;27:1123-7.

3. Centers for Disease C, Prevention. Nosocomial group a streptococcal infections associated with asymptomatic health-care workers-Maryland and California, 1997. MMWR Morb Mortal Wkly Rep. 1999;48:163-6.

4. Otter JA, Mutters NT, Tacconelli E, Gikas A, Holmes AH. Controversies in guidelines for the control of multidrug-resistant gram-negative bacteria in EU countries. Clin Microbiol Infect. 2015;21:1057-66.

5. Stapleton PJ, Murphy M, McCallion N, Brennan M, Cunney R, Drew RJ. Outbreaks of extended spectrum beta-lactamase-producing Enterobacteriaceae in neonatal intensive care units: a systematic review. Arch Dis Child Fetal Neonatal Ed. 2016;101:F72-8.

6. Gastmeier P, Stamm-Balderjahn S, Hansen S, Nitzschke-Tiemann F, Zuschneid I, Groneberg K, Ruden H. How outbreaks can contribute to prevention of nosocomial infection: analysis of 1,022 outbreaks. Infect Control Hosp Epidemiol. 2005;26:357-61. 
7. Vonberg RP, Weitzel-Kage D, Behnke M, Gastmeier P. Worldwide outbreak database: the largest collection of nosocomial outbreaks. Infection. 2011;39:29-34.

8. Snyder GM, D'Agata EM. Diagnostic accuracy of surveillance cultures to detect gastrointestinal colonization with multidrug-resistant gram-negative bacteria. Am J Infect Control. 2012:40:474-6.

9. Freire MP, Villela Soares Oshiro IC, Bonazzi PR, Pierrotti LC, de Oliveira LM, Machado AS, Van Der Heijdenn IM, Rossi F, Costa SF, Carneiro D'Albuquerque LA, Abdala E. Surveillance culture for multidrug-resistant gram-negative bacteria: performance in liver transplant recipients. Am J Infect Control. 2017;45:e40-e44.

10. Patterson JE, Vecchio J, Pantelick EL, Farrel P, Mazon D, Zervos MJ, Hierholzer WJ Jr. Association of contaminated gloves with transmission of Acinetobacter calcoaceticus var. anitratus in an intensive care unit. Am J Med. 1991;91:479-83.

11. Go ES, Urban C, Burns J, Kreiswirth B, Eisner W, Mariano N, Mosinka-Snipas K, Rahal JJ. Clinical and molecular epidemiology of acinetobacter infections sensitive only to polymyxin B and sulbactam. Lancet. 1994;344:1329-32.

12. Roberts SA, Findlay R, Lang SD. Investigation of an outbreak of multi-drug resistant Acinetobacter baumannii in an intensive care burns unit. J Hosp Infect. 2001;48:228-32

13. Tena D, Martinez NM, Oteo J, Saez D, Vindel A, Azanedo ML, Sanchez L, Espinosa A, Cobos J, Sanchez R, et al. Outbreak of multiresistant OXA-24and OXA-51-producing Acinetobacter baumannii in an internal medicine ward. Jpn J Infect Dis. 2013;66:323-6.

14. McDonald LC, Walker M, Carson L, Arduino M, Aguero SM, Gomez P, McNeil $P$, Jarvis WR. Outbreak of Acinetobacter spp. bloodstream infections in a nursery associated with contaminated aerosols and air conditioners. Pediatr Infect Dis J. 1998;17:716-22.

15. Archibald LK, Ramos M, Arduino MJ, Aguero SM, Deseda C, Banerjee S, Jarvis WR. Enterobacter cloacae and Pseudomonas aeruginosa polymicrobial bloodstream infections traced to extrinsic contamination of a dextrose multidose vial. J Pediatr. 1998;133:640-4.

16. Ehrenkranz NJ, Pfaff SJ. Mediastinitis complicating cardiac operations: evidence of postoperative causation. Rev Infect Dis. 1991;13:803-14.

17. van Nierop WH, Duse AG, Stewart RG, Bilgeri YR, Koornhof HJ. Molecular epidemiology of an outbreak of Enterobacter cloacae in the neonatal intensive care unit of a provincial hospital in Gauteng, South Africa. J Clin Microbiol. 1998:36:3085-7.

18. Afza M, Hawker J, Thurston H, Gunn K, Orendi J. An outbreak of Escherichia coli 0157 gastroenteritis in a care home for the elderly. Epidemiol Infect. 2006;134:1276-81.

19. Ryder RW, Buxton AE, Wachsmuth IK, Mason E, Barrett FF. Heat-stable enterotoxigenic Escherichia coli and necrotizing enterocolitis: lack of an association. J Pediatr. 1977;91:302-3.

20. Taneja N, Das A, Raman Rao DS, Jain N, Singh M, Sharma M. Nosocomial outbreak of diarrhoea by enterotoxigenic Escherichia coli among preterm neonates in a tertiary care hospital in India: pitfalls in healthcare. J Hosp Infect. 2003;53:193-7.

21. Curie K, Speller DC, Simpson RA, Stephens M, Cooke DI. A hospital epidemic caused by gentamicin-resistant Klebsiella aerogenes. J Hyg (Lond). 1978:80:115-23.

22. Lebessi E, Dellagrammaticas H, Tassios PT, Tzouvelekis LS, loannidou S, Foustoukou M, Legakis NJ. Extended-spectrum beta-lactamase-producing Klebsiella pneumoniae in a neonatal intensive care unit in the highprevalence area of Athens, Greece. J Clin Microbiol. 2002:40:799-804.

23. Coovadia YM, Johnson AP, Bhana RH, Hutchinson GR, George RC, Hafferjee IE. Multiresistant Klebsiella pneumoniae in a neonatal nursery: the importance of maintenance of infection control policies and procedures in the prevention of outbreaks. J Hosp Infect. 1992;22:197-205.

24. Fukigai S, Alba J, Kimura S, lida T, Nishikura N, Ishii Y, Yamaguchi K. Nosocomial outbreak of genetically related IMP-1 beta-lactamase-producing Klebsiella pneumoniae in a general hospital in Japan. Int J Antimicrob Agents. 2007;29:306-10.

25. Gupta A, Della-Latta P, Todd B, San Gabriel P, Haas J, Wu F, Rubenstein $D$, Saiman L. Outbreak of extended-spectrum beta-lactamase-producing Klebsiella pneumoniae in a neonatal intensive care unit linked to artificial nails. Infect Control Hosp Epidemiol. 2004;25:210-5.

26. Cassettari VC, Silveira IR, Balsamo AC, Franco F. Outbreak of extended-spectrum beta-lactamase-producing Klebsiella pneumoniae in an intermediate-risk neonatal unit linked to onychomycosis in a healthcare worker. J Pediatr. 2006; 82:313-6.
27. Boszczowski I, Nicoletti C, Puccini DM, Pinheiro M, Soares RE, Van der Heijden IM, Costa SF, Barone AA, Levin AS. Outbreak of extended spectrum beta-lactamase-producing Klebsiella pneumoniae infection in a neonatal intensive care unit related to onychomycosis in a health care worker. Pediatr Infect Dis J. 2005;24:648-50.

28. Yan JJ, Ko WC, Tsai SH, Wu HM, Wu JJ. Outbreak of infection with multidrugresistant Klebsiella pneumoniae carrying Bla(IMP-8) in a university medical center in Taiwan. J Clin Microbiol. 2001;39:4433-9.

29. Cassettari VC, da Silveira IR, Dropa M, Lincopan N, Mamizuka EM, Matté MH, Matté GR, Menezes PR. Risk factors for colonisation of newborn infants during an outbreak of extended-spectrum beta-lactamase-producing Klebsiella pneumoniae in an intermediate-risk neonatal unit. J Hosp Infect. 2009:71:340-7.

30. Nair D, Gupta N, Kabra S, Ahuja RB, Prakash SK. Salmonella Senftenberg: a new pathogen in the burns ward. Burns. 1999;25:723-7.

31. Zawacki A, O'Rourke E, Potter-Bynoe G, Macone A, Harbarth S, Goldmann D. An outbreak of Pseudomonas aeruginosa pneumonia and bloodstream infection associated with intermittent otitis externa in a healthcare worker. Infect Control Hosp Epidemiol. 2004:25:1083-9.

32. Falcão DP, Mendonça CP, Scrassolo A, De Almeida BB, Hart L, Farmer LH, Farmer JJ. Nursery outbreak of severe diarrhoea due to multiple strains of Pseudomonas aeruginosa. Lancet. 1972;2:38-40.

33. Widmer AF, Wenzel RP, Trilla A, Bale MJ, Jones RN, Doebbeling BN. Outbreak of Pseudomonas aeruginosa infections in a surgical intensive care unit: probable transmission via hands of a health care worker. Clin Infect Dis. 1993;16:372-6.

34. McNeil SA, Nordstrom-Lerner L, Malani PN, Zervos M, Kauffman CA. Outbreak of sternal surgical site infections due to Pseudomonas aeruginosa traced to a scrub nurse with onychomycosis. Clin Infect Dis. 2001;33:317-23.

35. Kienitz M. Outbreaks and sporadic cases of enteritis due to pseudomonas aeruginosa in premature babies and infants (author's transl). Infection. 1979; 7(Suppl 2):S231-5.

36. Moolenaar RL, Crutcher JM, San Joaquin VH, Sewell LV, Hutwagner LC, Carson LA, Robison DA, Smithee LM, Jarvis WR. A prolonged outbreak of Pseudomonas aeruginosa in a neonatal intensive care unit: did staff fingernails play a role in disease transmission? Infect Control Hosp Epidemiol. 2000;21:80-5

37. Sebert ME, Manning ML, McGowan KL, Alpern ER, Bell LM. An outbreak of Serratia marcescens bacteremia after general anesthesia. Infect Control Hosp Epidemiol. 2002;23:733-9.

38. Wilhelmi I, Bernaldo de Quiros JC, Romero-Vivas J, Duarte J, Rojo E, Bouza E. Epidemic outbreak of Serratia marcescens infection in a cardiac surgery unit. J Clin Microbiol. 1987;25:1298-300.

39. Jepson AP, McDougall C, Clark A, Bateman A, Williamson G, Kaufmann ME. Finger rings should be removed prior to scrubbing. J Hosp Infect. 2006;64: 197-8.

40. de Vries JJ, Baas WH, van der Ploeg K, Heesink A, Degener JE, Arends JP. Outbreak of Serratia marcescens colonization and infection traced to a healthcare worker with long-term carriage on the hands. Infect Control Hosp Epidemiol. 2006;27:1153-8.

41. Passaro DJ, Waring L, Armstrong R, Bolding F, Bouvier B, Rosenberg J, Reingold AW, McQuitty M, Philpott SM, Jarvis WR, et al. Postoperative Serratia marcescens wound infections traced to an out-of-hospital source. J Infect Dis. 1997 175:992-5.

42. Haller S, Eller C, Hermes J, Kaase M, Steglich M, Radonic A, Dabrowski PW Nitsche A, Pfeifer $Y$, Werner $G$, et al. What caused the outbreak of ESBLproducing Klebsiella pneumoniae in a neonatal intensive care unit, Germany 2009 to 2012? Reconstructing transmission with epidemiological analysis and whole-genome sequencing. BMJ Open. 2015;5:e007397.

43. Mutton KJ, Brady LM, Harkness JL. Serratia cross-infection in an intensive therapy unit. J Hosp Infect. 1981;2:85-91.

44. Sisson PR, Freeman R, Gould FK, Lightfoot NF. Strain differentiation of nosocomial isolates of Pseudomonas aeruginosa by pyrolysis mass spectrometry. J Hosp Infect. 1991;19:137-40.

45. Berlin RKI. Nosokomialer Ausbruch durch ESBL-bildende Klebsiella 310 pneumoniae im Zentrum für Kinderheilkunde Klinikum Bremen-Mitte 2011-2012.

46. Härtel C, Hartz A, Bahr L, Gille C, Gortner L, Simon A, Orlikowsky T, Müller A Körner T, Henneke P, et al. Media stories on NICU outbreaks lead to an increased prescription rate of third-line antibiotics in the Community of Neonatal Care. Infect Control Hosp Epidemiol. 2016;37:924-30. 
47. Decker BK, Lau AF, Dekker JP, Spalding CD, Sinaii N, Conlan S, Henderson DK, Segre JA, Frank KM, Palmore TN. Healthcare personnel intestinal colonization with multidrug-resistant organisms. Clin Microbiol Infect. 2018; 24:82 e81-4.

48. Kelsall NK, Griggs RK, Bowker KE, Bannister GC. Should finger rings be removed prior to scrubbing for theatre? J Hosp Infect. 2006;62:450-2.

49. Trick WE, Vernon MO, Hayes RA, Nathan C, Rice TW, Peterson BJ, Segreti J, Welbel SF, Solomon SL, Weinstein RA. Impact of ring wearing on hand contamination and comparison of hand hygiene agents in a hospital. Clin Infect Dis. 2003;36:1383-90.

50. Woodhead K, Taylor EW, Bannister G, Chesworth T, Hoffman P, Humphreys $\mathrm{H}$. Behaviours and rituals in the operating theatre. A report from the hospital infection society working party on infection control in operating theatres. J Hosp Infect. 2002;51:241-55.

51. Vonberg RP, Gastmeier P. Quality of outbreak descriptions in medical literature. Lancet Infect Dis. 2007;7:699-700.

52. Wieland K, Chhatwal P, Vonberg RP. Outbreak reporting a decade after ORION: where do we stand? Lancet Infect Dis. 2017;17:476.

53. Stone SP, Cooper BS, Kibbler CC, Cookson BD, Roberts JA, Medley GF, Duckworth G, Lai R, Ebrahim S, Brown EM, et al. The ORION statement: guidelines for transparent reporting of outbreak reports and intervention studies of nosocomial infection. Lancet Infect Dis. 2007:7:282-8.

54. D'Agata EM, Gautam S, Green WK, Tang YW. High rate of false-negative results of the rectal swab culture method in detection of gastrointestinal colonization with vancomycin-resistant enterococci. Clin Infect Dis. 2002; 34:167-72.

\section{Submit your next manuscript to BioMed Central and we will help you at every step:}

- We accept pre-submission inquiries

- Our selector tool helps you to find the most relevant journal

- We provide round the clock customer support

- Convenient online submission

- Thorough peer review

- Inclusion in PubMed and all major indexing services

- Maximum visibility for your research

Submit your manuscript at www.biomedcentral.com/submit

) Biomed Central 